\title{
WHY BUSINESS SCHOOL MANAGERS ARE A KEY \\ CORPORATE BRAND STAKEHOLDER GROUP
}

\author{
PROFESSOR JOHN M.T. BALMER
}

AND

DR WEI-YUE WANG

Professor John M.T. Balmer is Professor of Corporate Marketing at Brunel University Business School, Brunel University, London, UB8 $3 \mathrm{PH}$,

The United Kingdom

(Tel.: + 44(0) 1895 274000.Email: john.balmer@brunel.ac.uk)

Dr Wei-Yue Wang is lecturer in Strategy and Marketing at Salford University Business School, University of Salford, Manchester, M5 4WT,

The United Kindgom

(Tel: 44 (0) 161295 5623. Email: w.wang1@salford.ac.uk)

THIS IS A PRE-PUBLICATION VERSION OF AN ARTICLE WHICH WILL APPEAR IN THE JOURNAL:

INTERNATIONAL STUDIES OF MANAGEMENT AND ORGANIZATIONS (ISMO)

in 2015-2016.

KINDLY REFER TO THE JOURNAL (ISMO) FOR FULL REFERENCING DETAILS 


\title{
WHY BUSINESS SCHOOL MANAGERS ARE A KEY \\ CORPORATE BRAND STAKEHOLDER GROUP
}

\begin{abstract}
This study focuses on senior management cognitions of corporate brand building within leading (Financial Times-ranked) British business schools. The study reveals stakeholder theory to be highly apposite for corporate brand management and, importantly, confirms the pivotal role of senior managers in terms of corporate brand building and custodianship. The cognitions of senior business school managers confirmed the orthodox approach to corporate brand building and management where a multidisciplinary, service-focused, strategic-orientated and organizational-wide commitment is stressed. Mitchell et al. (1997) tripartite typology of stakeholders (power, legitimacy and urgency) is broadened in order to include necessity and responsibility that are highly germane for senior managers. The instrumental insights of this study demonstrate that in managing a corporate brand, senior managers should focus on organizational activities, institutional attitude, senior management advocacy and adherence on the part of organizational members.
\end{abstract}




\section{WHY BUSINESS SCHOOL MANAGERS ARE A}

\section{KEY \\ CORPORATE BRAND STAKEHOLDER GROUP}

Often overlooked in stakeholder theory, senior managers are a critically important stakeholder group for an organization's corporate brand and have a unique status in that as a distinct stakeholder they have responsibility for the day-to-day management and maintenance of the corporate brand. The context of this empirical study is distinct in that it marshals stakeholder theory in the context of corporate brands. Moreover, the study is distinct in that it focuses on senior managers cognitions of corporate brand building in leading (Financial Times ranked), UK-based, business schools and, moreover, appraises their significance as stakeholder group.

From the outset, the corporate brand notion (Balmer 1995) has stressed the custodianship role of senior managers in corporate brand building. This being noted, within the stakeholder and corporate brand canons, there is a lack of empirical research relating to senior managers' cognitions of the dimensions of corporate brand building activities. By ascertaining these dimensions the scope of senior management custodianship of corporate brands can be determined; the significance of senior managers in terms of shaping and directing the corporate brand can be ascertained; the importance they accord to other stakeholder groups can be discovered; and their significance as a stakeholder group can be validated.

\section{Stakeholder Theory and Senior Managers}

Freeman and Reed (1983) defined a stakeholder constituency in terms of a group on which the organization is dependent for its continued survival. A year later, Freeman (1984) delineated a stakeholder as a group (or individual) who can affect or is affected by the achievement of the organizations objectives. Mitchell et al (1997) noted that stakeholder groups should be assessed on the basis of their power (their ability to shape organizational/stakeholder relationships); legitimacy (their claims on the institution based on societal norms) and urgency (their demands for a preferential response).

Yet, taking account of the stakeholder insights of Freedman and Reed (1983) and Mitchell et al. (1997), it is difficult to argue that senior managers are not a key stakeholder group. Certainly, from a corporate brand management perspective, senior managers are viewed as a distinct and critically important stakeholder group in that they are charged with managing an organization's corporate brand (Balmer 1995).

In the context of stakeholder theory (Freeman 1984), senior managers have 
responsibility for coordinating, managing and prioritizing the interests of diverse stakeholder groups. Establishing a corporate-wide stakeholder orientation can be a key determinant of corporate success (Berman et al. 1999; Donaldson and Preston 1995; Jones and Wicks 1999). By inference, it is the responsibility of senior managers to foster such an orientation. The above being noted, to date, the recognition that senior managers are a stakeholder group with specific roles and responsibilities is sometimes disregarded. Moreover, stakeholder theory infrequently engages with corporate brands. As such, scholarship on this area is underdeveloped.

Although, stakeholder management is a key tenet of the corporate marketing (Balmer 1998; 2008) and corporate communication domains (Van Riel 1995), debate ranges as to the relative merits of stakeholder versus shareholder orientations (Micklethwaite and Wooldrige 2003). Whereas in Anglo-Saxon orientated countries, senior managers have traditionally focused on shareholders and on profit maximization, in Germany and Japan senior managers habitually pursued a societal, shareholder and profit generation motives (Micklethwaite and Wooldridge 2003, 81).

\section{British business schools}

Although the first professorial appointment in business (commerce) in the UK was made at Birmingham University 1901, it was in the immediate Second War era that University-level business education enjoyed exponential growth within Great Britain. This resulted in the establishment of business schools in London, Manchester, and Bradford.

Since the 1990s, ten environmental forces have accentuated the need for the corporate brand to be actively managed by senior managers (Gray and Balmer 1999). For business schools, the most germane of these forces are increased competition in the public and not-for-profit sectors (where Universities and Business Schools have developed appealing and distinctive corporate brand platforms); globalization (top business schools have realized they are part of a global market and face global competition); shortage of high caliber personnel (leading business schools appreciate the value of leading scholars which are in short supply); and public expectations for corporate social responsiveness (a realization that society increasingly places a premium on those corporate brands that demonstrate high-levels of corporate social responsiveness).

Given the above, since the 1950s, leading British business schools have enjoyed considerable success since they have taken account of the above. Moreover they are: international in outlook; accord importance to high-quality research and teaching; have a marketing orientation; and score well in business school league tables and accreditation bodies (Balmer et al. 2010).

\section{Business school corporate brands: Extant research}

To date, there is an absence of research that focuses on senior management cognitions of corporate brand building in leading British schools. Moreover, extant research on the corporate brand of business schools is slight. Existing empirical studies have focused on: social identity theory and student corporate brand identification within a leading business 
school' (Balmer and Liao 2007); internal stakeholders' perceptions of Manchester Business School (Roper and Davies 2007); strategic corporate brand change (Davies and Chun (2002); business schools and the MBA branding strategies (Gopalanet et. al., 2006); and business school corporate brand personality (Opoku et al. 2006).

\section{Corporate brands: The literature in context}

The corporate brand canon, with its formal recognition that organizations (and not just products and services) are brand-like, dates back to the mid-1990s (Balmer 1995). Since then corporate brand management is a field that has grown in significance both in academia and in business practice (Knox and Bickerton 2003; Mukherjee and Balmer 2007). For the main it has been marketing scholars (Balmer 1995; Lawer and Knox 2007; Leitch and Davenport 2007), but also those from organizational behavior (Hatch and Schultz 2003), who have advanced, corporate brand scholarship.

From the outset (Balmer 1995), corporate brands were defined as a distinct branding category; one that is derived from an organization's corporate identity; a branding type requiring commitment from all organizational members and, significantly, has a stakeholder focus; is multi-disciplinary in scope and is the responsibility of senior management -particularly the CEO (Knox 2004; Vallaster et al. 2012).

The stakeholder perspective is a key dimension of corporate brand management. At its essence, a corporate brand represents an informal contract (a covenant) between an organization and its brand community of stakeholders. Whereas legal ownership of the corporate brand is vested in an entity, the emotional ownership of the corporate brand (and thereby its real value), belongs with stakeholders (Balmer 2012).

It has been argued that corporate brands have a utility for stakeholders since they serve as powerful navigational tools for different stakeholder groups for a miscellany of purposes: employment, investment and, most importantly, consumer buying behavior (Balmer and Gray 2003). Ohnemus and Jenster (2007) established a correlation between corporate brand management and a corporate brand's financial performance. However, senior managers are rarely discussed as a distinct stakeholder group and their cognitions of the corporate brand management process have not been explored.

Recently, the notion that senior managers have parity with other stakeholder groups in corporate brand building has informed the marketing and management literatures. The co-creation (Hatch and Schultz 2010) and reverse market-orientation perspectives (Lawer and Knox 2007) are two, related, perspectives of this.

Mukherjee and Balmer (2007) identified four weaknesses with the corporate brand canon: (1) most articles are prescriptive and conceptual; (2) do not explore contingency scenarios; (3) focus on for-profit entities; and (4) often fail to make a theoretical contribution. This article addresses many of the above weaknesses. 


\section{Methodology}

Given the lack of empirical insight, a theory-building methodology - utilizing an embedded case study approach - informs this study. The research was undertaken within the inductive and qualitative research traditions. Typically, the qualitative research tradition is to describe, translate and, otherwise, come to terms with the meaning, and not the frequency, of certain more or less naturally occurring phenomenon in the social world (Van Maanen 1988).

The study focused on leading UK business schools included in the Financial Times (FT) list of the world's top 100 business schools. Of these UK thirteen schools, eight agreed to participate in the research, namely: Bradford University School of Management; Cass Business School, City University; Cranfield University School of Management; Durham University Business School; Judge Business School, Cambridge University; Lancaster University Management School; Said Business School, Oxford University; and Warwick University Business School.

The first stage of data collection consisted of five pilot interviews undertaken among senior managers in one leading business school. This enabled the topic guide used to guide the semi-structured interviews - to be fine-tuned (Gummesson, 1991). The second stage o of the study primarily consisted of thirty-seven semi-structured interviews with a variety of senior managers (Deans, Associate Deans and Directors/and other Senior Managers within the eight schools). Typically, the interviews were of $40-70$ minutes in length.

Other sources of data included documents and in-depth notes from a research diary. Triangulation of data was achieved by drawing on these diverse sources; in accordance with the qualitative and case study research traditions (Yin 1984; Eisenhardt 1989; Miles and Huberman 1994).

The analysis of data relied on the customary three-stage coding process (open, axial and selective codes) as is common in inductive research analyses where the data undergoes synthesis. The final stage-selective coding reduces codes into aggregate dimensions so as to form the empirical insight (Lincoln and Guba 1985; Miles and Huberman 1994).

For reasons of confidentiality and anonymity the names of individuals and school have not been revealed. Interviewees are identified by their general status and the business schools are referred to by number.

\section{Findings}

To reiterate, the primary objective of this study is to explicate the importance of senior managers as a key stakeholder group in terms of their conceptualization of corporate brand building and custodianship. From the data, four modes of corporate brand building characterized the cognitions of senior faculty and staff within leading British business schools, namely: activities, attitude, advocacy and adherence. (1) activities equate to specific senior management functions; (2) attitude equates to a senior management mind-set; (3) advocacy equates to the leadership function of senior manager and, in particular that of the Dean; and (4) adherence equates to a senior management realization that business school wide commitment to the corporate brand is imperative. 
The above insights are synthesized in table one below.

Table 1

Senior management cognitions of corporate brand building in leading British business schools

\begin{tabular}{|l|l|l|}
\hline MODE & EXPLANATION & VEHICLE \\
\hline $\begin{array}{l}\text { Activities: } \\
\text { (management functions) }\end{array}$ & $\begin{array}{l}\text { Key core management activities } \\
\text { for corporate brand building }\end{array}$ & $\begin{array}{l}\text { Strategic Management } \\
\text { Stakeholder Management } \\
\text { Design Management } \\
\text { Corporate Communications } \\
\text { Alliances with leading } \\
\text { international business schools }\end{array}$ \\
\hline $\begin{array}{l}\text { Attitude } \\
\text { (management mind-set) }\end{array}$ & $\begin{array}{l}\text { A senior management } \\
\text { philosophy for corporate brand } \\
\text { building }\end{array}$ & $\begin{array}{l}\text { Adopting a service focus } \\
\text { mind-set }\end{array}$ \\
\hline $\begin{array}{l}\text { Advocacy } \\
\text { (leadership) }\end{array}$ & $\begin{array}{l}\text { Senior management example } \\
\text { and guidance }\end{array}$ & $\begin{array}{l}\text { Senior Management Leadership } \\
\text { and responsibility }\end{array}$ \\
\hline $\begin{array}{l}\text { Adherence } \\
\text { (commitment from } \\
\text { organizational members) }\end{array}$ & $\begin{array}{l}\text { The requisite for } \\
\text { organizational-wide support }\end{array}$ & $\begin{array}{l}\text { Organizational commitment to } \\
\text { the corporate brand }\end{array}$ \\
\hline
\end{tabular}

\section{Activities}

The research showed that corporate brand building was an important senior management activity:

"Corporate) Brand building and management is very important, and the school brand needs to be actively managed" (Dean, Business School 7).

"Managing a school's (corporate) brand is important, and I think you have to manage the brand across a vast number of channels" (Director: Business School 8).

Moreover, across the schools, it was conceived as a multi-disciplinary activity, namely: (1) Strategy: "The relationship between building our corporate brand and our mission and vision should be absolutely hand in hand" (Director: Business School 4); (2) Internal and External Stakeholder Management: "We have a lot of connections with other (University) departments. It is a unique advantage for us" (Director: Business School). 
"A key strategy of the school is to build long-term relationships with leaders in the business world in a way that lets them actively contribute to the school" (Documentary Data: Business School 2);(3) Design Management: "We have spent a lot of money on this campus. In the past twenty years, millions of pounds. Much of the investment has gone into how the school is visualized" (Associate Dean: Business School 6);(4) Corporate Communications: "A virtual marketing group which meets every 2 weeks. It (involves) anyone who has any kind of responsibility for communications, external and internal" (Director: Business School 3);(5) Alliances: "We are working very hard to establish links with international schools and we are almost in the final stages of signing an agreement with Universities in the United States of America, China, and in Europe" (Dean: Business School 1).

\section{Attitude}

The data revealed that across the schools, senior managers, shared common attitudes in terms of the importance of corporate brand building. This was expressed through a service focus mind-set based on quality teaching, leading research, and innovative degree programs). There was, however, a realization that teaching, research and the reputation of individual degree programs materially influenced the extent to which esteem in a leading business school brand was held. However, there were some differences between those schools, which accorded prominence to teaching and those to research: "Delivering extremely high quality degree courses is equal to building the school's brand in reality" (Director: Business School 5)

"We are research oriented. I think business schools have to be research-oriented. Research is critical and the school's brand doesn't so much come from teaching. (Our) school's brand is more associated with research then teaching" (Director: Business school 2).

\section{Advocacy}

The data showed that senior managers not only recognized their role, but also the crucial role of the Dean in corporate brand building. The Dean was viewed as both a champion and leader of the corporate brand: Deans also recognized this fact.

"You then need to have a group of people because you can never do it by yourself. You need to be able to lead a group of people that will buy into your idea and then move the whole process together" (Dean, Business School 1).

"Business schools are highly political (in) that strategy and (management) decisions are very much based on one person - the Dean" (Director, Business School 2).

\section{Adherence}

The appreciation for there to be business school commitment to the corporate brand and the need for faculty and administrative,, and other staff to have a strong identification with the corporate brand also emerged as an important aspect of corporate 
brand building for senior business school managers. The following, indicative quote, is symptomatic of the above:

"I think building a brand should involve everybody. There is a conscious effort on the part of the management of this school to make sure that everybody understands that they are part of it." (Chief Operating Officer: Business School 3)

\section{Summary and Contribution}

Stakeholder theory notes that a stakeholder group is one that can affect and be affected by the achievement of an organization's objectives (Freeman 1984). Following a similar logic, the same can be said of corporate brands. Of all stakeholder groups none can affect an institution's corporate brand as much as senior managers. Uniquely they have responsibility for the management and maintenance of the corporate brand.

This study reveals the senior managers within top British business schools fully appreciate their custodianship role in managing and maintaining the corporate brand. It also shows that they are cognizant of the importance of meeting the interests of both internal and external stakeholder groups. Moreover, the cognitions of these senior managers reveal corporate brand management and building within leading business business schools is broad in scope and multidisciplinary in character. This study of senior British business school managers supports extant scholarship (Balmer 2012) which recognizes the importance of senior managers as a distinct stakeholder group which has responsibility for the shaping and guiding the corporate brand.

The research does have its limitations in that the findings are generalizable in an analytical but not in a statistical sense. The specific focus of this study is on is on leading British business school brands. Moreover, the research did not focus on what senior managers actually did but focused on their cognitions of their organization's corporate brand building activities.

Interestingly, senior management cognitions of corporate brand building did not reveal any affinity with the co-creation (Hatch Schultz, 2010) and reverse market-orientation perspectives (Lawer and Knox 2007). These perspectives, controversially, deem senior managers to have parity with other stakeholder groups who are deemed to be of equal importance in the design and management of corporate brands. However, senior managers did reveal that a stakeholder approach was important in corporate brand building terms. Noticeably, senior managers did not mention the need to meet their own wants and needs as a distinct stakeholder group.

The research is significant in that it confirms the importance of the corporate brand and, significantly, endorses an orthodox approach to corporate brand building. As such, a multidisciplinary, service-focused, strategic-orientated and organizational-wide commitment is stressed (Balmer 1995, 2012).

Top business schools are often seen to be exemplars of best practice in management and a key role of leading business schools is to promulgate, as well as promote, good practice. As such, managers might usefully reflect on the insights from this study. The context is also important, since these are leading and successful business 
school corporate brands and there appears to be an implicit correlation between strategic corporate brand building organizational successes. This warrants further research and other studies might usefully consider senior management's cognitions of corporate brand building in other sectors.

This study provides a salutary reminder that stakeholder theory as it applies to corporate brands -if it does not take into account senior managers as a unique and critically important stakeholder group-is not only difficult to operationalize but, also, is narrowly conceived. A stakeholder approach is not merely a general organizational concern but is, more specifically, an institutional-wide and, more specifically, a senior management responsibility. Stakeholder theory often ignores senior managers as a stakeholder group and yet of all the constituencies of an organization they are the group, which can most affect and can be significantly affected by their decisions and actions. As such, the theory should be reappraised in the light of this inquiry.

Finally, the notion that stakeholders should be appraised only in terms of their power, legitimacy and urgency as advocated by Mitchell et al (1997) does not adequately address the significant role of senior managers as corporate brand custodians. Following an orthodox perspective of corporate brand management, which has been corroborated by this study's research insights, issues relating to necessity and responsibility are also germane, as indicated in Table 2. For this reason, senior managers should be regarded as a key stakeholder group. As Freeman (1984) noted, a stakeholder group is one that can affect or is affected by the achievement of the organizations objectives and senior managers have a unique role in a corporate brand context.

Table 2

Corporate brands: importance of senior managers as a stakeholder group

\begin{tabular}{|c|c|c|}
\hline STAKEHOLDER ATTRIBUTE & ATTRIBUTE EXPLANATION & $\begin{array}{l}\text { APPLICABILITY TO SENIOR } \\
\text { MANAGERS AS A } \\
\text { STAKEHOLDER GROUP }\end{array}$ \\
\hline Power & $\begin{array}{l}\text { the ability to shape an } \\
\text { organizational/stakeholder } \\
\text { relationship }\end{array}$ & Yes \\
\hline Legitimacy & $\begin{array}{l}\text { a stakeholder group's claims on } \\
\text { the institution based on } \\
\text { societal norms }\end{array}$ & Yes \\
\hline Urgency & $\begin{array}{l}\text { demands made by a } \\
\text { stakeholder group for a } \\
\text { preferential response m. }\end{array}$ & Yes \\
\hline Necessity & A vital stakeholder relationship & $\begin{array}{l}\text { Yes (senior managers need to } \\
\text { design and implement } \\
\text { corporate brand strategies) }\end{array}$ \\
\hline Responsibility & $\begin{array}{l}\text { A specific and critical duty } \\
\text { required of a stakeholder group }\end{array}$ & $\begin{array}{l}\text { Yes (senior managers have } \\
\text { ultimate custodianship for the } \\
\text { corporate brand) }\end{array}$ \\
\hline
\end{tabular}




\section{References}

Balmer, J.M.T. 1995. "Corporate Branding and Connoisseurship." Journal of General Management 21(1): 22-46.

.2012. "Corporate Brand Management Imperatives: Custodianship, Credibility and Calibration". California Management Review 54(3): 1-28.

Balmer, J.M.T. and E.R. Gray. 2003. "Corporate Brands: What are they? What of them?" European Journal of Marketing 37(7/8): 972-997.

Balmer, J.M.T. and M-N, Liao. 2007. "Student Corporate Brand Identification: An Exploratory Study." Corporate Communications: An International Journal 12(4): 356-375.

Balmer, J.M.T., M-N, Liao and W-Y Wang. 2010. "Corporate Brand Identification and Corporate Brand Management: How Top Business Schools do it”. Journal of General Management 35(4): 77-102.

Berman, S.L., A.C. Wicks, S. Kotha, and T.M. Jones. 1999. "The Relationship Between Stakeholder Management Models and Firm Financial Performance.” Academy of Management Journal 42(5): 488-506.

Davies, G. and R. Chun. 2002. "Gaps between the Internal and External Perceptions of the Corporate Brand." Corporate Reputation Review 5(2/3): 144-159.

Donaldson, T., and L.E. Preston. 1995. "The Stakeholder Theory of the Corporation: Concepts, Evidence and Implications." Academy of Management Review 20(1): 65-91. Eisenhardt, K.M. 1989. "Building Theories from Case Study Research." Academy of Management Review 14(4): 532-550

Freeman, R.E. 1984. Strategic Management: A Stakeholder Approach. Englewood Cliffs, NJ: Prentice Hall.

Freeman, R.E. and D.L. Reed. 1983. "Stockholders and Stakeholders: A New Perspective on Corporate Governance." California Management Review 25(3): 88-106.

Gatfield, T., M. Barker, and P. Graham. 1999. "Measuring Communication Impact for University Advertising Materials." Corporate Communications: An International Journal 4(2): 73-79.

Gopalan, S; K. Stitts, and R.A. Herring. 2006. "An Exploratory Investigation of the Branding Strategies of the Top 50 Global MBA Programs." Journal of Business Research 5(2): 49-61.

Gray, E.R. and J.M.T. Balmer. 1999. "Corporate Identity and Corporate Communications: Creating a Competitive Advantage." Corporate Communications: An International Journal 4(4): 171-176.

Gummesson, E. 1991. Qualitative Methods in Management Research. London: Sage. Hatch, M., and M.J. Schultz. 2003."The Cycles of Corporate Branding: The Case of the LEGO Company." California Management Review 46(1): 6-26.

. 2010. "Towards a Theory of Brand Co-Creation and Implications for Brand

Governance." Journal of Brand Management 17(8): 590-604.

Jones, T.M., and A.C. Wicks. 1999. "Convergent Stakeholder Theory." Academy of 
Management Review 24(2): 206-221.

Knox, S. 2004. "Positioning and Branding Your Organization." Journal of Product and Brand Management 13(2): 105-115.

Knox, S. and D. Bickerton. 2003. "The Six Conventions of Corporate Branding." European Journal of Marketing 37(7/8): 998-1016.

Lawer, C. and S. Knox. 2007. "Reverse-Market Orientation and Corporate Brand Development. "International Studies of Management and Organizations 37(4):

64-83.

Leitch, S. and S. Davenport. 2007. "Corporate Brands and Social Brands." International Studies of Management and Organizations 37(4): 45-63.

Lincoln, Y.S, and E.G. Guba. 1985. Naturalistic Inquires. London: Sage.

Micklethwaite, J., and A. Wooldridge. 2003. The Company: A Short History from a

Revolutionary Idea. New York: Modern Library.

Miles, M. B. and A. M. Huberman. 1994. Qualitative Data Analysis: An Expanded

Sourcebook. Thousand Oaks, California: Sage.

Mitchell, R., B.R. Agle, and D.J. Wood.1997. "Toward a Theory of Stakeholder

Identification and Salience: Defining the Principle of Who and What Really

Counts." Academy of Management Review 22(4): 853-886.

Mukherjee, A. and J.M.T. Balmer. 2007. "New Frontiers and Perspectives in Corporate Brand Management: In Search of a Theory." International Studies of Management and Organizations 37(4): 3-19.

Ohnemus, L. and P.V. Jenster. 2007. "Corporate Brand Thrust and Financial Performance." International Studies of Management and Organization 37(4): 84-107.

Opoku, R., R.Abratt, and L. Pitt. 2006. "Communicating Brand Personality: Are the Websites Doing the Talking for the Top South African Business Schools?" Journal of Brand Management 14(1/2): 20-39.

Vallaster, C., A. Lindgreen and F. Maon. 2012. "Strategically Leveraging CSR: A Corporate Branding Perspective." California Management Review 54(3): 34-60. Van Maanen, J. 1988. Tales of the Field: On writing ethnography. Chicago: University of Chicago Press.

Yin, R.K. 1984.Case Study Research: Design and Methods. Newbury Park, CA: Sage. 